\title{
MYC chromosomal aberration in differential diagnosis between Burkitt and other aggressive lymphomas
}

\author{
Gabriella Aquino $^{1 \dagger}$, Laura Marra ${ }^{1 \dagger}$, Monica Cantile ${ }^{1}$, Annarosaria De Chiara ${ }^{1}$, Giuseppina Liguori ${ }^{1}$, Maria Pia Curcio ${ }^{1}$, \\ Rocco Sabatino ${ }^{1}$, Giuseppe Pannone ${ }^{2}$, Antonio Pinto ${ }^{3}$, Gerardo Botti ${ }^{1}$ and Renato Franco ${ }^{1 *}$
}

\begin{abstract}
Myc oncogenetic deregulation is abundantly described in several solid human cancer and lymphomas. Particularly, Burkitt's lymphoma belongs to the family of B Non Hodgkin aggressive lymphomas. Although it is morphologically characterized, immunophenotypic and cytogenetic diagnosis remains complex. In 2008, the WHO has introduced a new diagnostic class of aggressive B-cell lymphomas with features intermediate between BL and DLBCL. This diagnostic class represents a temporary container of aggressive B-cell lymphomas, not completely belonging to the $\mathrm{BL}$ and DLBCL categories. The importance of establishing a correct diagnosis would allow a better prognostic classification and a better therapeutic approach. In this review, we summarize the main diagnostic approaches necessary for appropriate diagnoses and we emphasize the importance of cytogenetic analysis of the oncogene Myc in the histopathological diagnosis and the prognostic/predictive stratification. In this contest, Myc represents the more involved gene in the development of these lymphomas. Therefore, we analyze the genetic aberrations causing its over-expression and the concomitant deregulation of molecular pathways related to it. We also propose a FISH approach useful in the diagnosis of these lymphomas.
\end{abstract}

Keywords: Burkitt Lymphoma, FISH, MYC, Aggressive non-Hodgkin B-cell lymphoma, Diffuse large B cell lymphoma, B-cell lymphoma unclassifiable

\section{Introduction}

Chromosomal translocations involving the immunoglobulin genes are common in B-cell non-Hodgkin lymphomas $[1,2]$. Some translocations are characterizing specific lymphoma histotypes and are often considered as cancer-initiating events [3]. For instance, $\mathrm{t}(8 ; 14)$ (q24; q32), that involves $M y c$ and IgH genes, is generally considered a hallmark of Burkitt Lymphoma (BL), but this translocation is not the only cytogenetic alteration observed in this type of lymphoma. BL is an aggressive non-Hodgkin B-cell lymphoma (B-NLH) characterized by the most rapidly growing cells [4]. It represents the first human tumor associated to a specific viral infection

\footnotetext{
* Correspondence: r.franco@istitutotumori.na.it

${ }^{\dagger}$ Equal contributors

${ }^{1}$ Pathology Unit, "Istituto Nazionale Tumori Fondazione G. Pascale" - Irccs, Naples, Italy

Full list of author information is available at the end of the article
}

and one of the first with a chromosomal rearrangement activating an oncogene [5,6]. Recent evidence suggests that lipid pathway is altered in BL. Indeed neoplastic cells are characterizated by the accumulation of lipid vacuoles [7]. Conventionally three clinical variants of BL have been described: endemic (eBL), sporadic (sBL) and HIV-related [8]. Histologically BL shows a "starry sky" appearance, due to death cells and scattered tingible-body-laden macrophages present in monomorphic B-cell population background and a high proliferation rate is always demonstrated [4]. Although these morphological characteristics are observed in the $\mathrm{BL}$, in adults a reliable diagnosis is very difficult to produce, since a subset of lymphomas with morphological features similar to $\mathrm{BL}$ are described [9]. Particularly differential diagnosis from some cases of diffuse large B cell lymphoma (DLBCL) and from B-cell lymphoma, unclassifiable, often results difficult. Even with the use of current diagnostic criteria, the distinction is not precise; in fact the agreement

\section{Biomed Central}


among expert hematopathologists on the pathological diagnosis of this subset of aggressive B lymphomas is only 53 percent $[10,11]$. The distinction between BL and DLBCL is clinically important, because these lymphomas are treated with different chemotherapeutic protocols and differ in their outcome [12].

Adult BL shows a rapdly developing disease, so diagnosis and staging are urgent because aggressive high-dose chemo-therapy should be started as soon as possible. Aggressive prophylaxis must be started immediately after diagnosis is confirmed [13]. However the interpretation of response is difficult because there isn't a single protocol [14]. In addition recently Rituximab has also been introduced for treatment of $\mathrm{BL}$ and $\mathrm{B}$ aggressive lymphomas [15].

\section{Review}

MYC physiology

$\mathrm{C}$-Myc is a transcription factor, playing a role in the control of the cell cycle progression. $C-M y c$ belongs to a transcription factors family that includes MYCL (L-Myc) and MYCN (N-Myc) and it is located on 8q24 chromosome [16]. Myc gene is composed by three exons and Myc mRNAs generate two isoforms of Myc polypeptides: the first, the shorter one, starts an internal AUG, the second, that is longer, initiates at a CUG [17]. The shorter one plays an important role in the stress response $[18,19]$ (Figure 1). In addition, it is involved in the regulation of many other biological activities, such as differentiation, apoptosis, angiogenesis, cell adhesion and motility, telomerase activity and cell metabolism [20]. Myc is considered the human oncogene more frequently deregulated in many types of cancer with subsequent, uncontrolled cell proliferation, genomic instability, apoptosis, escape of immune surveillance and cell immortalization [21,22].

Myc protein contains a basic region helix-loop-helixleucine zipper and modulates the expression of target genes by binding to specific DNA sequences (E-Box). Myc performs its function by dimerization with MAX, a leucine-zipper transcription factors family. Recently, it

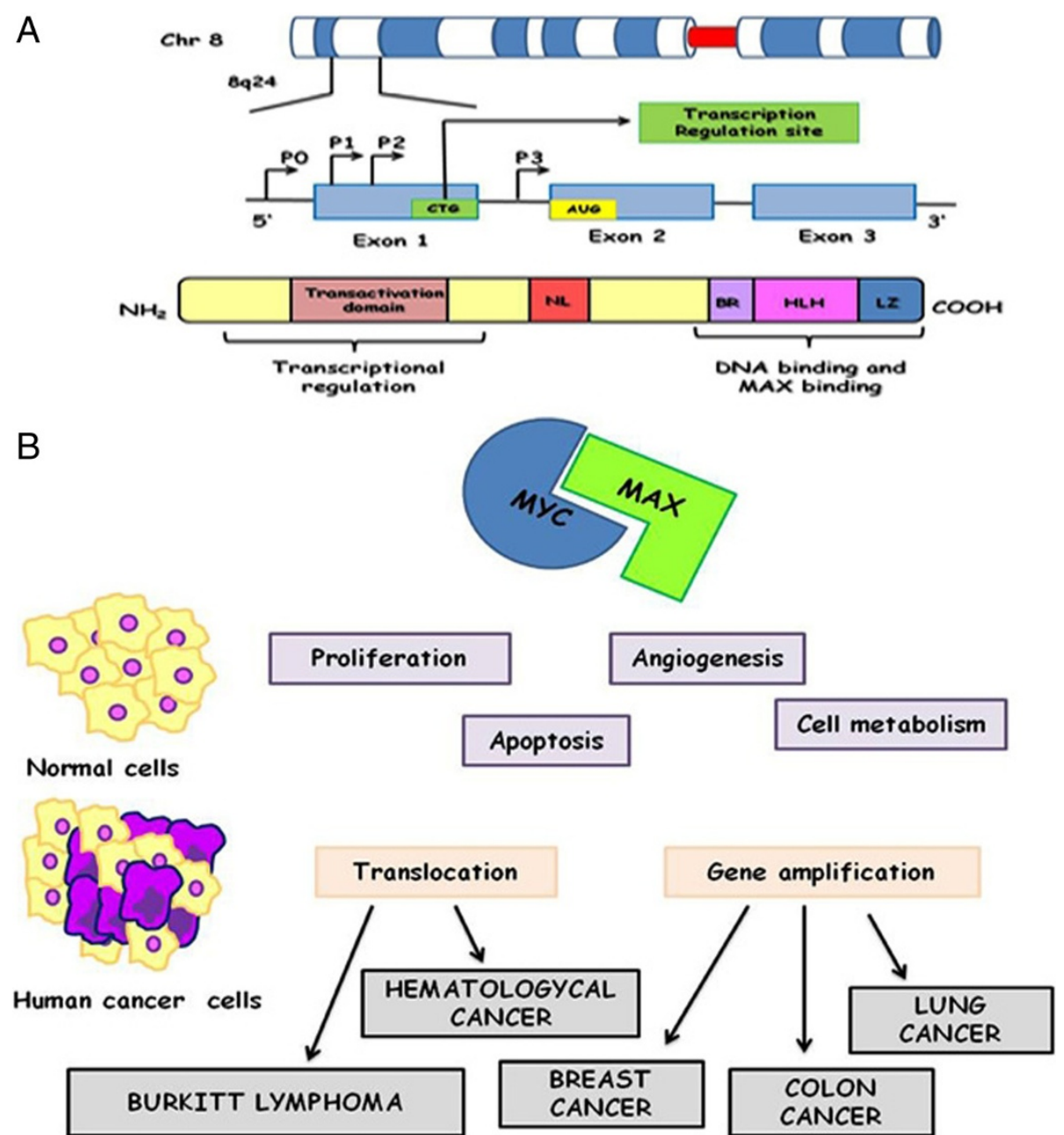

Figure 1 MYC. A) Schematic representation of MYC gene and protein domains; B) MYC alteration in human cancer. 
has been demonstrated that c-Myc expression in GCs (Germinal Center) is lower compared to naive and memory cells. Probably, this low expression could protect against Myc-induced genomic instability in the GC [23].

\section{Myc alteration in human cancer}

Myc oncogenetic deregulation could be induced by point mutations, gene amplification, translocation, epigenetic reprogramming, enhanced translation and increased protein stability [21]. The effects are C-Myc protein overexpression, demonstrated in $80 \%$ of breast cancers, $70 \%$ of colon cancers, $90 \%$ of gynecological cancers, $50 \%$ of hepatocellular carcinomas, $30 \%$ of lung cancer and a variety of hematological tumors [24]. Aberrant $M y c$ expression has also been identified in Prostatic Cancer where it has been proposed as a potential prognostic factor [25,26] (Figure 1B). Generally Myc gene amplification has been described as the most frequent molecular alteration in most of solid tumours [21]. In addiction Single-nucleotide Polymorphisms (SNPs) within 8q24 chromosomal region have been found to be associated with colorectal, breast, bladder, ovarian and prostate cancers [26,27]. Furthermore, point mutations are revealed in Myc $\mathrm{N}$-terminal domain (residues 44-65), in particular, the most frequently mutated residue is Thr- 58 . The phosphorylation of this residue has been shown to control c-Myc degradation and mutations, abolishing Thr-58, lead to an increased c-Myc half life in BL $[28,29]$. The translocation $t(8 ; 14)$ has been described as the most frequent aberration involving $M y c$ gene in $\mathrm{BL}$ with the immunoglobulin heavy chain $(\mathrm{IgH})$ gene as partner. Less common aberration involves light chain immunoglobulin genes (Ig $\lambda$ or Igk) in the translocations $\mathrm{t}(2 ; 8)$ and $\mathrm{t}(8 ; 22)$ [30]. The activation of the $M y c$ gene at $8 \mathrm{q} 24$ is considered the main pathogenetic feature of $\mathrm{BL}$, but the contribution of other genetic mutations to the disease is an important developing point [30]. In addition $M y c$ translocation is not only specifically observed in $\mathrm{BL}$ but it can occur in other hematological malignancies. Indeed Myc rearrangement is observed in 5-10\% of diffuse large B-cell lymphomas and up to $50 \%$ of high-grade Bcell lymphomas other than Burkitt lymphomas [31]. In these tumours, $M y c$ translocations can also involve nonIG partners [24].

\section{Molecular pathways associated to MYC overexpression in Burkitt lymphoma}

Myc translocation in $\mathrm{BL}$ is considered as a lymphoma initiating event, in other lymphomas it may also occur as a secondary event during disease progression [3]. Well documented oncogenetic alterations are associated to other intracellular pathways.

Recently C. Love et al. have highlighted a series of gene mutations in BL. For example, ID3 (inhibitor of
DNA binding protein) gene mutations produce a twofold higher gene expression in BL cells when compared to DLBCL [32]. ID3 mutation is associated to increased $\mathrm{G}$ to $\mathrm{S}$ phase cell cycle progression correlated to higher expression of cell cycle pathway genes, such as E2F1, CDK7, MCM10 and with an higher expression of known Myc target genes. This phenomenon, through ID3 mimetics, could represent the possibility of a potential therapeutic approach in BL [32].

Using animal models, many studies have shown that the translocation involving $M y c$ could be mediated by citidinedeaminase (AICDA) and that it is not activated by the recombinase (RAG1/2). This suggests the presence of somatic hypermutation or class switch recombination, that may be detected in normal tissue $[33,34]$.

Several papers described an overexpression of NF-kB (Nuclear Factor kappa-light-chain-enhancer of activated B cells) both in DLBCL and HL and its lower expression in BL. Klapproth et al. suggest in a study realized on mice and human that in $c-M y c$ transformated lymphoma cells, NF-kB-pathway is deregulated. Therefore they concluded that c-MYC overexpression sensitizes cells to NF- $\mathrm{kB}-\mathrm{in}-$ duced apoptosis, and the absence of NF- $\mathrm{kB}$ signaling is an assumption for MYC-mediated tumorigenesis [35].

Another study tried to explain the possible role of IP3K (Inositol 1,4,5-Trisphosphate 3-kinase) and Myc in primary events of lymphomagenesis, using mouse models of BL. The results show a significant activation of IP3K pathway, especially in cells where the signal of NF-kB is off [36]. Recently, IP3K overexpression has been found in human BL, suggesting a functional role in BL pathogenesis [35]. The involvement of NF-kB and IP3K pathways might have implication for the development of therapies against MYC-positive tumours. Recent studies highlight c-Myc influence on the Retinoblastoma $(\mathrm{Rb})$ pathways. $\mathrm{Rb}$ gene family is composed by three $(\mathrm{Rb}, \mathrm{pRb} 2 / \mathrm{p} 130$ and p107) cell cycle regulator protein members. Cinti et al. showed that several genetic alterations disrupt the nuclear localization of the retinoblastoma-related gene RB2/p130 in human tumor cell lines and primary tumors [37]. In particular, mutation of $R B 2 / p 130$ caused the upregulation of cyclins E1 and A2, involved in cell cycle progression from G1 to S-phase, and the inactivation of the transcription factor E2F4 (typically increasing during the S phase) [38]. This alteration is more frequent in endemic BL and lesser in sporadic BL. However, RB2/p130 mutation has not been included into molecular signatures that distinguish $\mathrm{BL}$ and DLBCL, suggesting that RB2/p130 deregulation was common in all B-non-Hodgkin lymphomas (NHLs), and not exclusive for BL pathogenesis [39].

The INK4/ARF locus encodes two tumour suppressor genes, p16 and p14 that distinctively regulate $\mathrm{Rb}$ and p53 pathways. Human and murine studies have showed that the simultaneous c-Myc iperactivation and INK4/ARF 
inactivation are an essential step during the development of BL, conferring a further growth advantage and apoptosis protection to the cells [40,41]. Moreover, c-Myc, p14 and p16 are degraded with proteasome-dependent mechanism, and a less ubiquitination is demonstrated in BL. These evidences suggest that proteasome inhibitors may be further considered in the treatment of BL [42]. Recent studies have highlighted that miRNAs (small non coding RNA) may have a role in malignant transformation in several solid tumors, but little is known about their expression and deregulation in malignant lymphomas [43]. In particular, hsa-miR-155 was found to be highly expressed in 90\% of Hodgkin's lymphomas and in diffuse large B-cell lymphomas. Moreover recent studies have underlined its role in B-cell differentiation. Furthermore, the miR-17-92 cluster was described as a transcriptional target of c-Myc and it was over-expressed during lymphomagenesis [44]. Other studies have assessed that hsa-miR-127 up-regulation in EBV positive BL confirming different pathogenetic mechanisms between EBV-positive and EBV-negative BL [45]. We have schematized in Figure 2 all the previously discussed pathways correlated to $M y c$ gene aberration.

\section{Detection of $M Y C$ gene/protein alteration}

Several studies have demonstrated distinctive complex karyotypes (CK) in BL and DLBCL. Havelange et al. have identified recurrent alterations associated with
Myc rearrangements in 84 aggressive B-cell lymphomas by multicolor fluorescence in situ hybridization (M-FISH). They concluded that BL karyotypes were less complex and aneuploid than other lymphomas with $M y c$-rearrangement. This condition suggests that $\mathrm{BL}$ with $\mathrm{CK}$ are indeed different from other aggressive MYC-rearranged lymphomas, usually showing wider genetic complexity [46]. Several Comparative genomic hybridization (CGH) studies highlight genomic imbalances in BL. Garcìa et al. found chromosomes 12q, Xq, $22 q, 20 q, 9 q$ gains, and chromosomes $13 q$ and $4 q$ losses. Moreover they found high level of amplification in the regions 1q23-31, 6p12-p25, 8p22-23 [47]. Anyway previous studies have determined that $\mathrm{BL}$ has a simple karyotype $<$ or $=2$ additional abnormalities and it is associated to better overall survival respect to other $B$ aggressive lymphomas, this condiction is generally observed in BLs [48]. Gains or amplifications of chromosomes 1q and 7q (respectively $20 \%$ and $10 \%$ of $\mathrm{BL}$ ) have been associated with worse clinic outcome and also all 13q chromosomal abnormalities have been related to an aggressive behaviour $[47,49,50]$. Furthermore, recently, a comparative analysis between whole-genome oligonucleotide array $\mathrm{CGH}$ analysis and FISH in a Burkitt's lymphoma-derived cell lines, showed three minimal critical regions (MCR) localized on Chr 1q harboring several genes such as BCA2, PIAS3 and MDM4 and AKT3. These regions appear critically involved in BL prognosis [51].

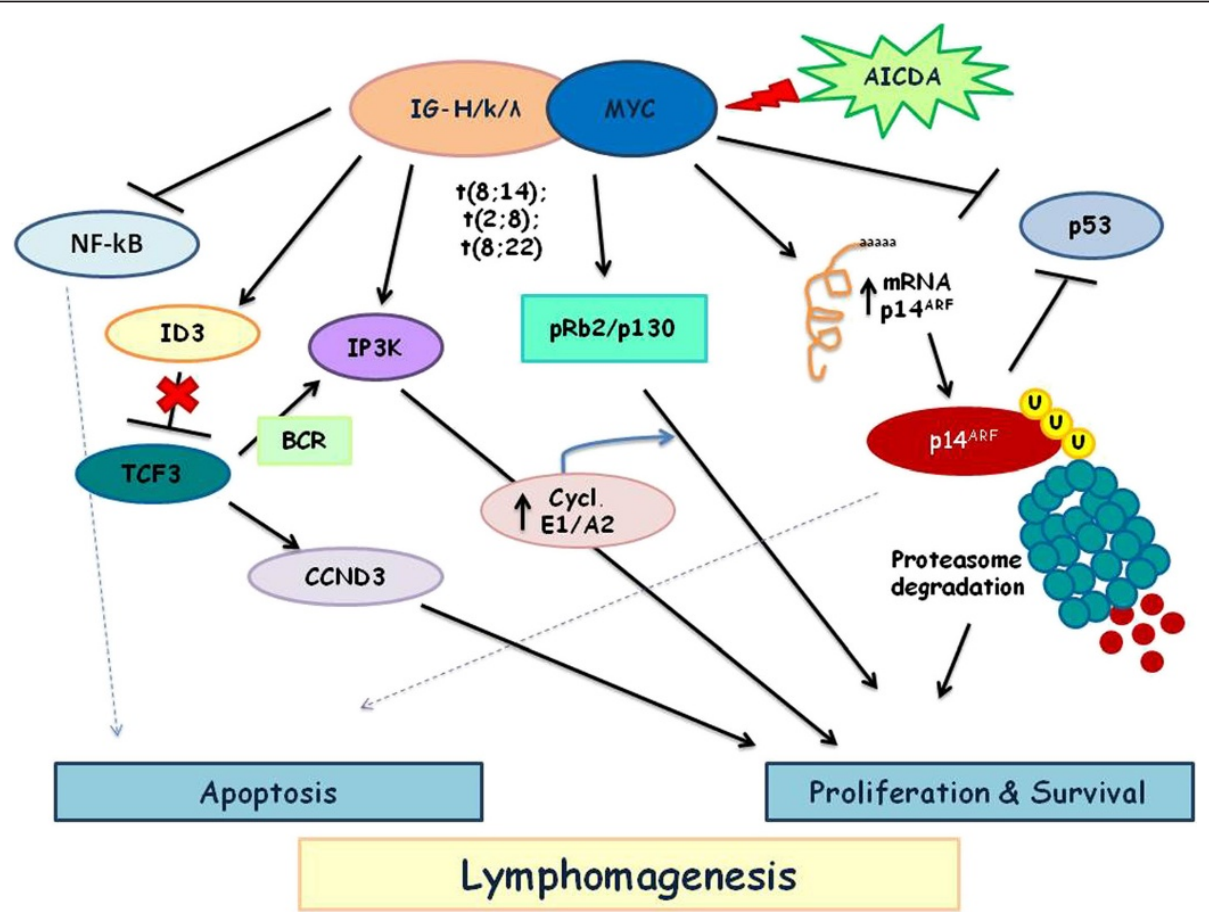

Figure 2 Schematic representation of MYC translocation and molecular pathways involved in lymphomagenesis. 
However, the $M y c$ translocation remains the main cytogenetic signature of BL as shown by its routinely use in several diagnostic algorithms. This investigation is fundamental in differential diagnosis with other lymphomas morphologically similar to BL but with atypical immunophenotype or genetic signatures.

Hummel et al. proposed a "BL similarity index", based on the analysis of 58 genes, classifying aggressive NHL into molecular $\mathrm{BL}(\mathrm{mBL})$, intermediate cases, and non molecular Burkitt. They analysed 220 mature aggressive B-cell lymphomas, and identified a consistent gene panel characteristic of molecular BL. These genes also included several target genes of the nuclear factor- $\mathrm{k} B$ pathway (i.e., BCL2A1, FLIP, CD44, NFKBIA, BCL3, and $S T A T 3)$ that normally distinguished activated B-cell-like $(\mathrm{ABC})$ or germinal-center B-cell-like lymphomas (GC) $[52,53]$. Through this index yet not all cases with morphologic or immunophenotypical features of Burkitt's lymphoma were classified as mBL. Molecular signature was strongly supported from the genetic analysis that defines three groups: i) the myc-simple group characterized by $I G-M y c$ fusion and a low number of chromosomal imbalances (complexity score $<6, M Y C$ translocation could be the primary oncogenic event) largely overlapped with the molecular $\mathrm{BL}$ and associated with a favourable clinical outcome; ii) Myc-complex status (complexity score $>6, M y c$ translocation could be the second oncogenic event) associated with a poor outcome, independently of age and clinical stage corresponding to the intermediate group; iii) $M y c$ negative group including non molecular Burkitt cases [53].

On the basis of current literature, Bellan et al. suggested a practical approach for BL diagnosis. To distinguish among BL, DLBCL and the provisional category of "unclassifiable B-cell lymphoma", with intermediate features between DLBCL and BL (BCLU), they used cytogenetic, molecular and immunohistochemical techniques, selecting a large panel of antibodies. In particular, FISH analysis was performed to detect the translocations involving $M y c, B C L 2$ and BCL6 through commercially available probes [54].

$M y c$ translocation could be easily detected through the use of commercial probes by breaking apart or by dual fusion strategy used for FISH analyses. The first strategy allows, in a single approach, to assess the integrity of the $M y c$ gene, but it does not provide information about the translocation partner. Known translocation partners of Myc gene could be detected using the second strategy (Figure 3). Several commercial probes are available, but they detect separately the different $M y c$ partners. In fact some Break Apart probes, investigating the presence of $M y c$ rearrangements in the locus corresponding to $\operatorname{Ig} \lambda$
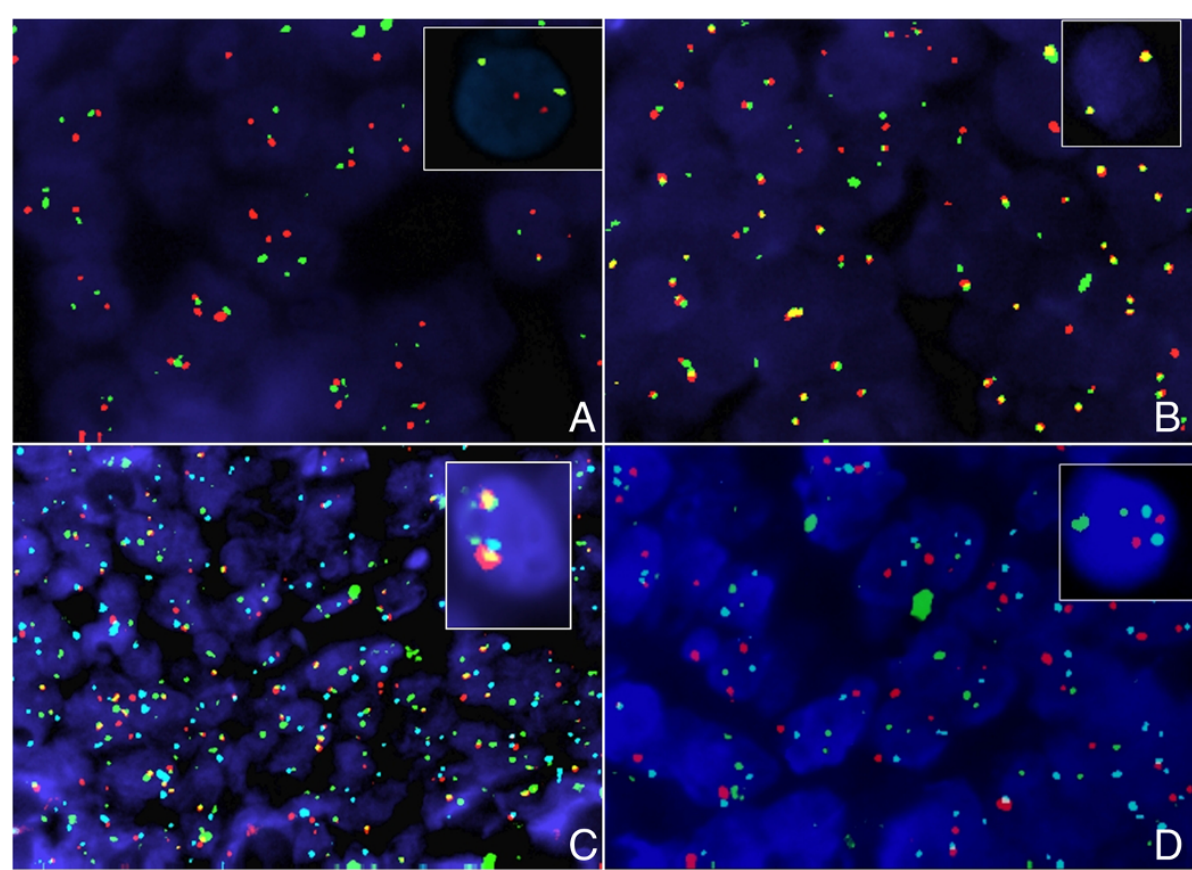

Figure 3 Above, FISH assay shows the MYC locus rearrangement with a break-apart probe (Vysis LSI MYC Dual Color Break Apart Rearrangement Probe Kit). A. MYC rearrangement-positive tumor cells, showing one yellow fusion signal, one orange and one green signals; B. Absence of MYC translocation, showing fusion signal patterns; Below, FISH assay shows the IGH/MYC/CEP8 Tri-Color Dual Fusion probe (Vysis IGH/MYC/CEP 8 Tri-Color DF FISH Probe Kit): C. The reciprocal $t(8 ; 14)$ in tumor cells showed a pattern of one orange, one green, two orange/ green fusions, and two aqua centromeric signals; D. Absence of reciprocal translocation showed the two aqua, two orange, and two green signals pattern. 
or Igк, are available. The only commercial dual colour dual fusion $M y c$ probe allows the translocation t (8:14) assessment. There are no commercial probes to investigate the non-IG Myc partners. The Myc break apart probe combined with the previously described probes are necessary to detect this subset of translocations.

Naresh et al. proposed in the diagnostic approach of $\mathrm{BL}$ an immunohistochemistry and FISH scoring system, based on three phases. Particularly, the first phase is based on the scoring of both the morphological features and a small immunohistochemistry panel detections, including BCL2 and CD10 antibodies. If the cumulative score is $\geq 5$, the diagnosis of BL can be proposed; if the score is $<3$ the diagnosis is not BL. The unresolved cases with intermediate score should be further scored through a larger panel of immunohistochemistry, such as ki67 (score 0-1-2), CD38 (score 0-1) and CD44 (score $0-1$ ). Only if cumulative scores is $\geq 8$, diagnosis of $\mathrm{BL}$ is definitively proposed. Finally, If this phase is uncertain, FISH analysis, including Myc $\backslash$ IG translocation and rearrangements of BCL2 and BCL6 should be crucial. If cumulative scores is $\geq 8$ : diagnosis of $\mathrm{BL}$; if the score is between 6 and 7: BL not excluded. Through this approach is possible enable to give lead to a precise diagnosis of $\mathrm{BL}$ in more than $90 \%$ cases [55].

Instead, Salaverria et al. propose a genetic model of pathogenesis of high-grade B cell lymphomas "gray zone", related to genetic aberration and age. The gray zone represents hybrid zone between classical BL and classical DLBCL, and contain "secondary Burkitt-transformed lymphomas" and many indeterminate lymphomas. Cytogenetically Sporadic BLs in children and adults are similar. Both groups are characterized by the same low genomic complexity including the same genetic aberrations. A correct subclassification of mature aggressive B-cell lymphomas in adults directly influence the therapeutic strategy. This genetic model shows that real adult BLs are very rare and that the BL with more genetic alteration is extremely difficult to find. In this contest, the distinctive feature of $\mathrm{BL}$ is represented by its low genomic complexity [56].

$M y c$ translocation has not only diagnostic value but it is also a powerful prognostic indicator in several lymphomas.

Myc translocation is associated to poor prognosis in other B aggressive lymphomas. Indeed LI S. et al. showed several lymphoma cases with a germinal center B-cell immunophenotype carrying $M y c$ and BCL2 rearrangements and clinically aggressive behaviour, independently of their morphological appearance [57]. Pei Lin et al. assert that the only $M y c$ aberration, in unclassifiable B-cell lymphoma, identifies patient subsets, requiring more aggressive therapy than R-CHOP [58].

However, $M y c$ can be regulated by other mechanisms inducing its increased protein expression and its hyperactivation $[59,60]$. FISH is unable to detect genetic deregulation that affects gene expression on the transcriptional and translational levels unlike immunohistochemical analysis [61]. For a long time the Myc evaluation by immunohistochemestry has been hampered by a lack of anti-MYC antibodies that are suitable to detect the increased protein expression. However, recently a new commercial, Myc antibody (clone Y69; Epitomics, Burlingame, CA) seems to be useful in the diction of myc overexpression, independently from molecular mechanism. This monoclonal antibody targets the Myc protein- $\mathrm{N}$ terminus. This Myc antibody shows a typical nuclear staining and it has been proposed a significant diagnostic cut-off in BL for the immunoscoring when higher than $40 \%$. Several recent studies proposed to introduce this antibody in a novel diagnostic alghorithm.

Green et al. analyse a group of DLBCL both trough immunohistochemistry for Myc, BCL2, CD10, BCL6, and MUM1/interferon regulatory factor 4 , and FISH for $M y c$ and BCL2. They concluded that FISH analysis identified Double-Hit Lymphoma (DHL) in 6\% of patients, while immunohistochemical MYC and BCL2 analyses identified a double-hit group that comprised $29 \%$ of patients. These cases were significantly associated with shorter OS $(\mathrm{P}<.001)$, and shorter progression-free survival (PFS; $\mathrm{P}<.001$ ), concluding that the only MYC and Bcl2 immunohistochemestry defined a large subset of DLBCLs strongly associated with poor outcome in patients treated with R-CHOP [62].

Finally, Horn et al. proposed to introduce a novel diagnostic approach using Myc antibody. They suggest a combined immunohistochemical and FISH score to predict outcome in DLBCL patients (score 0, when BCL2 <70\% and $\mathrm{MYC}<40 \%$, score $1 \mathrm{MYC}$ and $\mathrm{Bcl} 2$ expression near to cut off and score 3, when $\mathrm{Bcl} 2$ and MYC expression is more than cut-off) [63].

The routinely diagnostic application of Myc antibody is not yet applied. Recent studies show Myc antibody use in DLBCL where the percentage of Myc translocation is very low [64]. In the future Myc antibody could be used for the other B aggressive lymphomas, BL and BCLU, to detect Myc altered expression independently from the mutations.

\section{Conclusion}

\section{Diagnostic algorithms}

Detection of the $M y c$ translocation is currently performed by conventional cytogenetics, Southern blot, and polymerase chain reaction-based methods. Nevertheless, all these methods can fail to detect IG-Myc fusions [65]. The most reliable method is cytogenetic analysis by fluorescence in situ hybridization (FISH). Nowadays the molecular genetics is fully integrated into the routine diagnostic of 


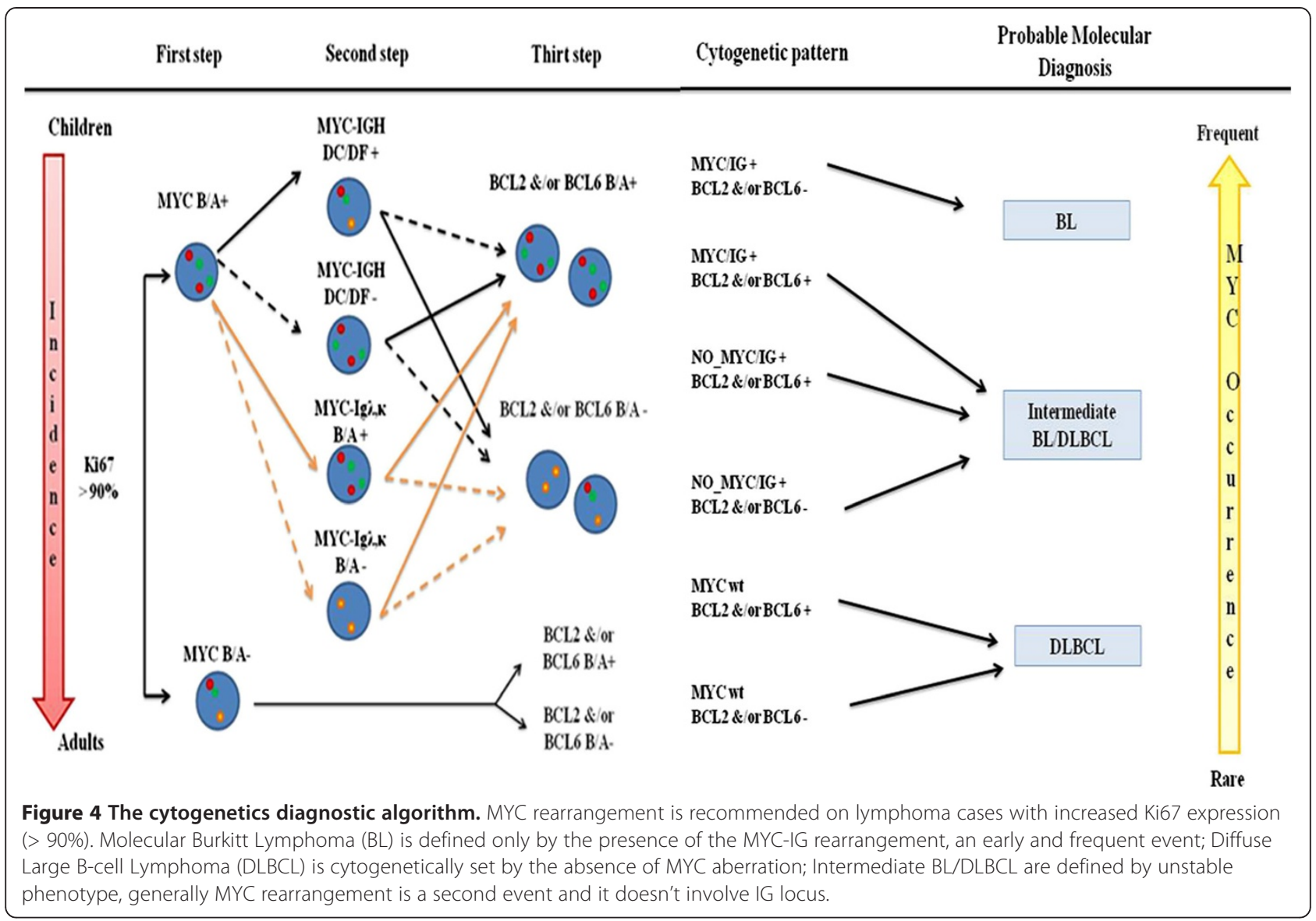

lymphomas. The Gold standard method is the CGH Array but this analysis has not been introduced into routine diagnostic laboratories because it is labour-intensive and it has a high rate of failure [29]. Thus in the future, the development of a FISH assay for simultaneous detection of all known Burkitt abnormalities will be necessary.

We summarized a cytogenetic diagnostic "flowchart" for a better and safer histopathologic diagnosis of Burkitt (Figure 4). We recommend a first FISH approach using $M y c$ Break Apart probe on lymphoma cases with increased ( $>90 \%) \mathrm{Ki67}$, to identify all positive samples for Myc translocations. BCL2 and BCL6 translocations using Break Apart probes will be performed on all negative samples. Finally on the positive specimens should evaluate also the presence of IG-Myc translocation through the use of a Dual colour dual fusion $M y c-I G H$ probe and IGK and IGL Break Apart probes. Then, BCL2 and BCL6 status should be investigated. In our opinion, this is the best approach to avoid misdiagnosis of molecular BL but it is useful only if it is integrated with morphologic and immunophenotypic evaluation. The diagnosis of $\mathrm{BL}$ and other aggressive B cell Lymphomas, with or without $M y c$ breakpoints, represents an important start-point for future clinical trials to establish different therapeutical strategies for these lymphomas. Although the FISH-based algorithmic approach results an important tool for BL diagnosis, it is not easily accessible in most of the pathology laboratories because it is an expensive method and so it remains a speculative analysis.

\section{Competing interests}

The authors declare that they have no competing interests.

\section{Authors' contributions}

GA and LM drafted the manuscript. All authors read and approved the final manuscript.

\section{Author details}

'Pathology Unit, "Istituto Nazionale Tumori Fondazione G. Pascale" - Irccs, Naples, Italy. ${ }^{2}$ Medicine and Surgery Department, Foggia University, Foggia, Italy. ${ }^{3}$ Haematology Unit, "Istituto Nazionale Tumori Fondazione G. Pascale" Irccs, Naples, Italy.

Received: 21 June 2013 Accepted: 17 September 2013 Published: 30 September 2013

\section{References}

1. Lenz G, Staudt LM: Aggressive lymphomas. N Engl J Med 2010, 362:1417-1429.

2. Willis TG, Dyer MJ: The role of immunoglobulin translocations in the pathogenesis of B-cell malignancies. Blood 2000, 96:808-822. 
3. Seifert M, Scholtysik R, Küppers R: Origin and pathogenesis of $B$ cell lymphomas. Methods Mol Biol 2013, 971:1-25.

4. Leoncini L, Raphaël M, Stein H, Harris NL, Jaffe ES, Kluin PM: Burkitt lymphoma. In WHO classification of tumours of haematopoietic and lymphoid tissues, Volume 2. 4th edition. Edited by IARC Press. 2008:262-264.

5. Dalla Favera R, Bregni M, Erikson J, Patterson D, Gallo RC, Croce CM: Human C-myc one gene is located on the region of chromosome 8 that is translocated in Burkitt lymphoma cell. Proc Natl Acad Sci USA 1982, 79:7824-7827.

6. Taub R, Kirsch I, Morton C, Lenoir G, Swan D, Tronick S, Aaronson S, Leder P: Translocation of the c-myc gene into the immunoglobulin heavy chain locus in human Burkitt lymphoma and murine plasmacytoma cells. Proc Natl Acad Sci USA 1982, 79:7837-7841.

7. Ambrosio MR, Piccaluga PP, Ponzoni M, Rocca BJ, Malagnino V, Onorati M, De Falco G, Calbi V, Ogwang M, Naresh KN, Pileri SA, Doglioni C, Leoncini L, Lazzi S: The alteration of lipid metabolism in Burkitt lymphoma identifies a novel marker: adipophilin. PLOS One 2012, 7:e44315.

8. Newton R, Ziegler J, Beral V, Mbidde E, Carpenter L, Wabinga H, Mbulaiteye S, Appleby P, Reeves G, Jaffe H: Uganda Kaposi's Sarcoma study group: a case-control study of human immunodeficiency virus infection and cancer in adults and children residing in Kampala, Uganda. Int I Cancer 2001, 92:622-627.

9. Perkins AS, Friedberg JW: Burkitt lymphoma in adults. Hematology Am Soc Hematol Educ Program 2008, 341-348. doi:10.1182/asheducation-2008.1.341.

10. Magrath I, Jaffe ES, Bhatia K: Burkitt's lymphoma. In Neoplastic hematopathology. Edited by Knowles DM. Philadelphia: Lippincott Williams \& Wilkins; 2001:953-986.

11. Armitage JO, Armitage JO, the Non-Hodgkin's Lymphoma Classification Project: A clinical evaluation of the International Lymphoma study group classification of non-Hodgkin's lymphoma: the non-Hodgkin's Lymphoma classification project. Blood 1997, 89:3909-3918.

12. Pfreundschuh $M$, Trümper $L$, Kloess $M$, Schmits R, Feller AC, Rübe $C$, Rudolph C, Reiser M, Hossfeld DK, Eimermacher H, Hasenclever D, Schmitz $\mathrm{N}$, Loeffler M: Two-weekly or 3-weekly CHOP chemotherapy with or without etoposide for the treatment of elderly patients with aggressive lymphomas: results of the NHL-B2 trial of the DSHNHL. Blood 2004, 104:634-641.

13. Molyneux EM, Rochford R, Griffin B, Newton R, Jackson G, Menon G, Harrison CJ, Israels T, Bailey S: Burkitt's lymphoma. Lancet 2012, 379:1234-1244.

14. Magrath IT, Haddy TB, Adde MA: Adults and children with small noncleaved-cell lymphoma have a similar excellent outcome when treated with the same chemotherapy regimen. J Clin Onc 1996, 14:925-934.

15. Thomas DA, Faderl S, O'Brien S, Bueso-Ramos C, Cortes J, Garcia-Manero G, Giles FJ, Verstovsek S, Wierda WG, Pierce SA, Shan J, Brandt M, Hagemeister FB, Keating MJ, Cabanillas F, Kantarjian H: Chemoimmunotherapy with hyper-CVAD plus rituximab for the treatment of adult Burkitt and Burkitt-type lymphoma or acute lymphoblastic leukemia. Cancer 2006, 106:1569-1580.

16. Depinho RA, Hatton $K$, Ferrier $P$, Zimmerman $K$, Legouy E, Tesfaye A, Collum R, Yancopoulos G, Nisen P, Alt F: Myc family genes: a dispersed multigene family. Ann Clin Res 1986, 18:284-289.

17. Blackwood EM, Eisenman RN: Max: a helix-loop-helix zipper protein that forms a sequence-specific DNA-binding complex with Myc. Science 1991, 251:1211-1217.

18. Spotts GD, Patel SV, Xiao Q, Hann SR: Identification of downstreaminitiated c-Myc proteins which are dominant-negative inhibitors of transactivation by full-length c-Myc proteins. Mol Cell Biol 1997, 17:1459-1468.

19. Xiao Q, Claassen G, Shi J, Adachi S, Sedivy J, Hann SR: Transactivationdefective c-MycS retains the ability to regulate proliferation and apoptosis. Genes Dev 1998, 12:3803-3808.

20. Henriksson M, Lüscher B: Proteins of the Myc network: essential regulators of cell growth and differentiation. Adv Cancer Res 1996, 68:109-182.

21. Vita M, Henriksson M: The Myc oncoprotein as a therapeutic target for human cancer. Semin Cancer Biol 2006, 16:318-330.

22. Dang CV: MYC on the path to cancer. Cell 2012, 149:22-35.

23. Klein U, Tu Y, Stolovitzky GA, Keller JL, Haddad J Jr, Miljkovic V, Cattoretti G, Califano A, Dalla-Favera R: Transcriptional analysis of the B cell germinal center reaction. Proc Nti Acad SCI U S A 2003, 100:2639-2644.
24. Gardner LB, Lee LA, Dang CV: C-myc protooncogene. In Encyclopedia of cancer. Edited by Bertino JR. Amsterdam: Elsevier Science; 2002:555-561.

25. Gurel B, Iwata T, Koh CM, Yegnasubramanian S, Nelson WG, De Marzo AM: Molecular alterations in prostate cancer as diagnostic, prognostic, and therapeutic agents? Adv Anat Pathol 2008, 15:319-331.

26. Quinn DI, Henshall SM, Sutherland RL: Molecular markers of prostate cancer outcome. Eur J Cancer 2005, 41:858-888.

27. Brisbin AG, Asmann YW, Song H, Tsai YY, Aakre JA, Yang P, Jenkins RB, Pharoah P, Schumacher F, Conti DV, Duggan DJ, Jenkins M, Hopper J, Gallinger S, Newcomb P, Casey G, Sellers TA, Fridley BL: Meta-analysis of $8 q 24$ for seven cancers reveals a locus between NOV and ENPP2 associated with cancer development. BMC Med Genet 2011, 5(12):156.

28. Bahram F, von der Lehr N, Cetinkaya C, Larsson LG: c-Myc hot spot mutations in lymphomas result in inefficient ubiquitination and decreased proteasome-mediated turnover. Blood 2000, 95:2104-2110.

29. Coller HA, Grandori C, Tamayo P, Colbert T, Lander ES, Eisenman RN, Golub TR: Expression analysis with oligonucleotide microarrays reveals that MYC regulates genes involved in growth, cell cycle, signaling, and adhesion. Proc Natl Acad Sci USA 2000, 97:3260-3265.

30. Brady G, MacArthur GJ, Farrell PJ: Epstein-Barr virus and Burkitt lymphoma. J Clin Pathol 2007, 60:1397-1402.

31. Philip Kluin et Ed Schuuring: Molecular cytogeneitis of Lymphoma: where do we stand in 2010? Histopathology 2011, 58:128-144.

32. Love C, Sun Z, Jima D, Li G, Zhang J, Miles R, Richards KL, Dunphy CH, Choi WW, Srivastava G, Lugar PL, Rizzieri DA, Lagoo AS, Bernal-Mizrachi L, Mann KP, Flowers CR, Naresh KN, Evens AM, Chadburn A, Gordon LI, Czader MB, Gill Jl, His ED, Greenough A, Moffitt AB, McKinney M, Banerjee A, Grubor V, Levy S, Dunson DB, et al: The genetic landscape of mutations in Burkitt lymphoma. Nat Genet 2012, 44:1321-1325.

33. Guikema JE, Schuuring E, Kluin PM: Structure and consequences of IGH switch breakpoints in Burkitt lymphoma. J Natl Cancer Inst Monogr 2008, 39:32-36.

34. Janz S: Genetic and environmental cofactors of Myc translocations in plasma cell tumor development in mice. J Natl Cancer Inst Monogr 2008, 39:37-40.

35. Klapproth K, Sander S, Marinkovic D, Baumann B, Wirth T: The IKK2/NF$\{$ kappa\}B pathway suppresses MYC-induced lymphomagenesis. Blood 2009, 114:2448-2458.

36. Sander S, Calado DP, Srinivasan L, Köchert K, Zhang B, Rosolowski M, Rodig SJ, Holzmann K, Stilgenbauer S, Siebert R, Bullinger L, Rajewsky K: Synergy betweenPI3K signaling and MYC in Burkitt lymphomagenesis. Cancer Cell 2012, 22:167-179.

37. Cinti C, Leoncini L, Nyongo A, Ferrari F, Lazzi S, Bellan C, Vatti R, Zamparelli A, Cevenini G, Tosi GM, Claudio PP, Maraldi NM, Tosi P, Giordano A: Genetic alterations of the retinoblastoma-related gene RB2/p130 identify different pathogenetic mechanisms in and among Burkitt's lymphoma subtypes. Am J Pathol 2000, 156:751-760.

38. Cinti C, Claudio PP, Howard CM, Neri LM, Fu Y, Leoncini L, Tosi GM, Maraldi NM, Giordano A: Genetic alterations disrupting the nuclear localization of the retinoblastoma-related gene RB2/p130 in human tumor cell lines and primary tumors. Cancer Res 2000, 60:383-389.

39. Leoncini L, Bellan C, Cossu A, Claudio PP, Lazzi S, Cinti C, Cevenini G, Megha T, Laurini L, Luzi P, Orcioni GF, Piccioli M, Pileri S, Giardino C, Tosi P, Giordano A: Retinoblastoma-related p107 and pRb2/p130 proteins in malignant lymphomas: distinct mechanisms of cell growth control. Clin Cancer Res 1999, 5:4065-4072.

40. Eischen CM, Weber JD, Roussel MF, Sherr CJ, Cleveland JL: Disruption of the ARF-Mdm2-p53 tumor suppressor pathway in Myc-induced lymphomagenesis. Genes Dev 1999, 13:2658-2669.

41. Schmitt CA, McCurrach ME, De Stanchina E, Wallace-Brodeur RR, Lowe SW: INK4a/ARF mutations accelerate lymphomagenesis and promote chemoresistance by disabling p53. Genes Dev 1999, 13:2670-2677.

42. Roberti A, Rizzolio F, Lucchetti C, De Leval L, Giordano: Ubiquitin-mediated protein degradation and methylation-induced gene silencing cooperate in the inactivation of the INK4/ARF locus in Burkitt lymphoma cell lines. Cell Cycle 2011, 10:127-134.

43. Volinia S, Calin GA, Liu CG, Ambs S, Cimmino A, Petrocca F, Visone R, lorio M, Roldo C, Ferracin M, Prueitt RL, Yanaihara N, Lanza G, Scarpa A, Vecchione A, Negrini M, Harris CC, Croce CM: A microRNA expression signature of human solid tumors defines cancer gene targets. Proc Natl Acad Sci U S A 2006, 103:2257-2261. 
44. Lawrie $\mathrm{CH}$ : MicroRNA expression in lymphoma. Expert Opin Biol Ther 2007, 7:1363-1374.

45. De Falco G, Antonicelli G, Onnis A, Lazzi S, Bellan C, Leoncini L: Role of EBV in microRNA dysregulation in Burkitt lymphoma. Semin Cancer Biol 2009, 19:401-406

46. Havelange V, Ameye G, Théate I, Callet-Bauchu E, Mugneret F, Michaux L, Dastugue N, Penther D, Barin C, Collonge-Rame MA, Baranger L, Terré C, Nadal N, Lippert E, Laï JL, Cabrol C, Tigaud I, Herens C, Hagemeijer A, Raphael M, Libouton JM, Poirel HA: Patterns of genomic aberrations suggest that Burkitt lymphomas with complex karyotype are distinct from other aggressive B-cell lymphomas with MYC rearrangement. Genes Chromosomes Cancer 2013, 52:81-92.

47. García JL, Hernandez JM, Gutiérrez NC, Flores T, González D, Calasanz MJ, Martínez-Climent JA, Piris MA, Lopéz-Capitán C, González MB, Odero MD San Miguel JF: Abnormalities on $1 \mathrm{q}$ and $7 \mathrm{q}$ are associated with poor outcome in sporadic Burkitt's lymphoma: a cytogenetic and comparative genomic hybridization study. Leukemia 2003, 17:2016-2024.

48. Seegmiller AC, Garcia R, Huang R, Maleki A, Karandikar NJ, Chen W: Simple karyotype and bcl-6 expression predict a diagnosis of Burkitt lymphoma and better survival in IG-MYC rearranged high-grade B-cell lymphomas. Mod Pathol 2010, 23:909-920.

49. Boerma EG, Siebert R, Kluin PM, Baudis M: Translocations involving $8 q 24$ in Burkitt lymphoma and other malignant lymphomas: a historical review of cytogenetics in the light of todays knowledge. Leukemia 2009, 23:225-234

50. Poirel HA, Cairo MS, Heerema NA, Swansbury J, Aupérin A, Launay E, Sanger WG, Talley P, Perkins SL, Raphaël M, McCarthy K, Sposto R, Gerrard M, Bernheim A, Patte C, FAB/LMB 96 International study committee: Specific cytogenetic abnormalities are associated with a significantly inferior outcome in children and adolescents with mature B-cell non-Hodgkin's lymphoma: results of the FAB/LMB 96 international study. Leukemia 2009, 23:323-331.

51. Toujani S, Dessen P, Ithzar N, Danglot G, Richon C, Vassetzky Y, Robert T, Lazar V, Bosq J, Da Costa L, Pérot C, Ribrag V, Patte C, Wiels J, Bernheim A: High resolution genome-wide analysis of chromosomal alterations in Burkitt's lymphoma. PLoS One 2009, 4:e7089.

52. Wring G, Tan B, Rosenwald A, Hurt EH, Wiestner A, Staudt LM: A gene expression- based method to diagnose clinically distinct subgroups of diffuse large B cell lymphoma. Proc Natl Acad Sci USA 2003, 100:9991-9996.

53. Hummel M, Bentink S, Berger $H$, Klapper W, Wessendorf S, Barth TF, Bernd HW, Cogliatti SB, Dierlamm J, Feller AC, Hansmann ML, Haralambieva E, Harder L, Hasenclever D, Kühn M, Lenze D, Lichter P, Martin-Subero Jl, Möller P, Müller-Hermelink HK, Ott G, Parwaresch RM, Pott C, Rosenwald A, Rosolowski M, Schwaenen C, Stürzenhofecker B, Szczepanowski M, Trautmann H, Wacker HH, Molecular Mechanisms in Malignant Lymphomas Network Project of the Deutsche Krebshilfe, et al: A biologic definition of Burkitt's lymphoma from transcriptional and genomic profiling. N Engl Med 2006, 354:2419-2430.

54. Bellan C, Stefano L, De Giulia F, Rogena EA, Lorenzo L: Burkitt lymphoma versus diffuse large B-cell lymphoma: a practical approach. Hematol Oncol 2010, 28:53-56.

55. Naresh KN, Ibrahim HA, Lazzi S, Rince P, Onorati M, Ambrosio MR, BilhouNabera C, Amen F, Reid A, Mawanda M, Calbi V, Ogwang M, Rogena E, Byakika B, Sayed S, Moshi E, Mwakigonja A, Raphael M, Magrath I, Leoncini $L$ : Diagnosis of Burkitt lymphoma using an algorithmic approachapplicable in both resource-poor and resource-rich countries. $\mathrm{Br} J$ Haematol 2011, 154:770-776.

56. Salaverria I, Siebert R: The gray zone between Burkitt's lymphoma and diffuse large B-cell lymphoma from a genetics perspective. J Clin Oncol 2011, 29:1835-1843.

57. Li S, Lin P, Fayad LE, Lennon PA, Miranda RN, Yin CC, Lin E, Medeiros LJ: Bcell lymphomas with MYC/8q24 rearrangements and IGH@BCL2/t(14;18) (q32;q21): an aggressive disease with heterogeneous histology, germinal center B-cell immunophenotype and poor outcome. Mod Pathol 2012, 25:145-156.

58. Lin P, Dickason TJ, Fayad LE, Lennon PA, Hu P, Garcia M, Routbort MJ, Miranda R, Wang X, Qiao W, Medeiros LJ: Prognostic value of MYC rearrangement in cases of $B$-cell lymphoma, unclassifiable, with features intermediate between diffuse large B-cell lymphoma and Burkitt lymphoma. Cancer 2012, 118:1566-1573.
59. Lenz G, Wright GW, Emre NC, Kohlhammer H, Dave SS, Davis RE, Carty S, Lam LT, Shaffer AL, Xiao W, Powell J, Rosenwald A, Ott G, Muller-Hermelink HK, Gascoyne RD, Connors JM, Campo E, Jaffe ES, Delabie J, Smeland EB, Rimsza LM, Fisher RI, Weisenburger DD, Chan WC, Staudt LM: Molecular subtypes of diffuse large B-cell lymphoma arise by distinct genetic pathways. Proc Natl Acad Sci USA 2008, 105:13520-13525.

60. Bea S, Zettl A, Wright G, Salaverria I, Jehn P, Moreno V, Burek C, Ott G, Puig X, Yang L, Lopez-Guillermo A, Chan WC, Greiner TC, Weisenburger DD, Armitage JO, Gascoyne RD, Connors JM, Grogan TM, Braziel R, Fisher Rl, Smeland EB, Kvaloy S, Holte H, Delabie J, Simon R, Powell J, Wilson WH, Jaffe ES, Montserrat E, Muller-Hermelink HK: Diffuse large B-cell lymphoma subgroups have distinct genetic profiles that influence tumor biology and improve gene-expression-based survival prediction. Blood 2005, 106:3183-3190.

61. Ventura RA, Martin-Subero JI, Jones M, McParland J, Gesk S, Mason DY, Siebert R: FISH analysis for the detection of lymphoma-associated chromosomal abnormalities in routine paraffin-embedded tissue. J Mol Diagn 2006, 8:141-151.

62. Green TM, Young KH, Visco C, Xu-Monette ZY, Orazi A, Go RS, Nielsen O, Gadeberg OV, Mourits-Andersen T, Frederiksen M, Pedersen LM, Møller MB: Immunohistochemical double-hit score is a strong predictor of outcome in patientswith diffuse large B-cell lymphoma treated with rituximab plus cyclophosphamide, doxorubicin, vincristine, and prednisone. J Clin Oncol 2012, 30:3460-3467.

63. Horn H, Ziepert M, Becher C, Barth TF, Bernd HW, Feller AC, Klapper W, Hummel M, Stein H, Hansmann ML, Schmelter C, Möller P, Cogliatti S, Pfreundschuh M, Schmitz N, Trümper L, Siebert R, Loeffler M, Rosenwald A, Ott G, German High-Grade Non-Hodgkin Lymphoma Study Group: MYC status in concert with BCL2 and BCL6 expression predicts outcome in diffuse large B-cell lymphoma. Blood 2013, 121:2253-2263.

64. Johnson NA, Slack GW, Savage KJ, Connors JM, Ben-Neriah S, Rogic S, Scott DW, Tan KL, Steidl C, Sehn LH, Chan WC, Iqbal J, Meyer PN, Lenz G, Wright G, Rimsza LM, Valentino C, Brunhoeber P, Grogan TM, Braziel RM, Cook JR, Tubbs RR, Weisenburger DD, Campo E, Rosenwald A, Ott G, Delabie J, Holcroft C, Jaffe ES, Staudt LM: Concurrent expression of MYC and BCL2 in diffuse large B-cell lymphoma treated with rituximab plus cyclophosphamide, doxorubicin, vincristine, and prednisone. J Clin Oncol 2012, 30:3452-3459.

65. Guikema JE, De Boer C, Haralambieva E, Smit LA, Van Noesel CJ, Schuuring E, Kluin PM: IGH switch breakpoints in Burkitt lymphoma: exclusive involvement of noncanonical class switch recombination. Genes Chromosomes Cancer 2006, 45:808-819.

doi:10.1186/1750-9378-8-37

Cite this article as: Aquino et al:: MYC chromosomal aberration in differential diagnosis between Burkitt and other aggressive lymphomas. Infectious Agents and Cancer 2013 8:37.

\section{Submit your next manuscript to BioMed Central and take full advantage of:}

- Convenient online submission

- Thorough peer review

- No space constraints or color figure charges

- Immediate publication on acceptance

- Inclusion in PubMed, CAS, Scopus and Google Scholar

- Research which is freely available for redistribution 